\title{
Expression status of S100A14 and S100A4 correlates with metastatic potential and clinical outcome in colorectal cancer after surgery
}

\author{
HONG-YI WANG ${ }^{1 *}$, JING-YU ZHANG $^{2 *}$, JIAN-TAO CUI $^{2}$, XIAO-HUI TAN ${ }^{2}$, \\ WEN-MEI LI ${ }^{2}$, JIN GU$^{1}$ and YOU-YONG LU² \\ ${ }^{1}$ Department of Surgery, ${ }^{2}$ Laboratory of Molecular Oncology, Key Laboratory of Carcinogenesis and Translational Research, \\ Peking University School of Oncology, Beijing Cancer Hospital and Institute, Beijing 100142, P.R. China
}

Received July 30, 2009; Accepted August 14, 2009

DOI: $10.3892 /$ or_00000604

\begin{abstract}
To investigate whether S100A14 and S100A4 expression correlates with metastatic potential and prognosis in colorectal cancer (CRC), we firstly used RT-PCR analysis to detect mRNA expression of S100A14 and S100A4 in 40 pairs of fresh tumor samples matched with adjacent normal tissues. We then evaluated the clinical significance of our findings with immunohistochemistry on 115 samples of formalin-fixed and paraffin-embedded tumors on tissue microarrays. Typically, we identified decreased S100A14 mRNA levels $(52.5 \%, 21 / 40)$, and increased S100A4 mRNA levels $(70.0 \%, 28 / 40)$ in primary CRC samples. In addition, downregulated or absent S100A14 expression was detected in $56.5 \%$ of samples $(65 / 115)$ and was correlated with poor differentiation $(\mathrm{P}=0.010)$. In contrast, overexpressed S100A4 was detected in $57.4 \%$ of samples (66/115) and was associated with lymph node metastasis $(\mathrm{P}=0.001)$. Simultaneous S100A14 low-expression and S100A4 high-expression was correlated with high $\mathrm{CRC}$ metastatic potential $(\mathrm{P}<0.001)$. Taken together, the signature derived from the combined expression status of S100A14 and S100A4 could be a valuable prognostic indicator in CRC.
\end{abstract}

\section{Introduction}

The S100 proteins are a family of 21 small, acidic proteins with calcium binding motifs. The S100 family of calcium binding proteins comprises at least 25 members, forming the largest group of EF-hand signaling proteins in humans (1).

Correspondence to: Professor You-Yong Lu, Laboratory of Molecular Oncology, Peking University School of Oncology, Beijing Cancer Hospital and Institute, Beijing 100142, P.R. China

E-mail: yongylu@public.bta.net.cn or youyonglu@sina.com

${ }^{*}$ Contributed equally

Key words: S100A14, S100A4, colorectal cancer
Although structurally similar, the $\mathrm{S} 100$ proteins have been shown to be involved in a variety of different physiological functions in human tissues, such as calcium homeostasis, protein phosphorylation, cell proliferation and differentiation, the cytoskeleton, extracellular signal transduction, intercellular adhesion and motility as well as cancer metastasis (2-6). Currently, the S100 family is of great interest because some members show deregulated expression in human diseases, especially in cancer.

Among the S100 family members, S100A4, a known metastasis-associated gene, was isolated by subtractive hybridization of non-metastatic cells from metastatic mouse mammary adenocarcinoma cells (8). It is implicated in metastasis because of its overexpression in many human solid cancers including gastric, colorectal and breast cancers (9-14). Additionally, the expression of S100A4 in breast cancer, esophageal squamous cell cancer, gall bladder cancer, nonsmall cell lung cancer, gastric cancer and colorectal cancer (CRC) has been associated with poor survival (14-19).

The S100 proteins are expressed in many tissues; however, in general, each protein is preferentially expressed in one particular tissue. For instance, S100A14 was first cloned and characterized by analyzing a human lung cancer cell line subtraction cDNA library, and was mapped to human chromosome 1q21 (20). S100A14 mRNA was initially shown to be expressed in several normal human tissues of epithelial origin, and most abundantly in normal colorectal mucosa. Significantly, down-regulated levels of S100A14 mRNA were detected in colorectal tumor tissues (20). S100A1, S100A2, S100A11, S100A14 and S100Z have been postulated to have a tumor suppressor function because of their decreased expression in many types of human cancer (21-24).

Although overexpression of S100A4 in CRC has been reported, little is known about the expression levels of S100A14 in matched samples of non-cancerous and cancerous parts of colorectal tumors. There is no available data on co-expression of S100A14 and S100A4 in the development and progression of CRC. In the present study, we evaluated the expression levels of S100A14 and S100A4 mRNA in five CRC cell lines and in 40 matched sample pairs of primary $\mathrm{CRC}$ and adjacent normal colorectal mucosa. We 
also performed parallel immunohistochemical staining of S100A14 and S100A4 to analyze their association with clinicopathological characteristics in 115 CRCs, and tried to clarify the distinct roles of S100A14 and S100A4 in the progression of human CRC.

\section{Materials and methods}

Patients and tissues. Specimens were obtained from 115 patients with primary CRC diagnosed and treated in the Department of Surgery, School of Oncology, Peking University, from 1999 to 2001. Fresh tissue samples were transferred immediately to liquid nitrogen and stored at $-80^{\circ} \mathrm{C}$ for later RT-PCR. Tissue microarray blocks containing formalin-fixed and paraffin-embedded human tissues were constructed in our laboratory as described previously (25). Informed consent was obtained from all patients. All patients underwent surgery and none of the patients had received chemotherapy or radiation therapy. Histopathological analyses were performed independently by two pathologists. Tumor stage was classified according to the American Joint Committee on Cancer (AJCC) TNM classification (26). In addition, the patients were divided into proximal and distal tumor groups according to the anatomic location of their tumors, as described previously (27).

Cell lines and cell culture. CRC cell lines RKO, SW480, SW620, LoVo and HT29 were cultured in Dulbecco's modified Eagle's medium (DMEM, Gibco BRL, Grand Island, NY, USA), supplemented with 5\% fetal bovine serum (FBS), 100 units/ml penicillin and $100 \mu \mathrm{g} / \mathrm{ml}$ streptomycin. All cell lines were maintained at $37^{\circ} \mathrm{C}$ in $5 \% \mathrm{CO}_{2}$.

Extraction of total RNA and RT-PCR. Total RNAs were isolated from fresh tissues using TRIzol reagent (Qiagen, USA). The prepared RNA (5 $\mu \mathrm{g}$ ) was mixed with oligo-dT primer and was reverse-transcribed with MMLV reverse transcriptase (Promega, USA) for $60 \mathrm{~min}$ at $37^{\circ} \mathrm{C}$, followed by PCR amplification with specific primers for the $S 10014$ gene (F, 5'-ACT CTC ACC AAA GGA CCA GAC AC-3', R, 5'-CAG GTG CAG GCT AGG GTA CAG-3') or the S100A4 gene (F, 5'-CCT GGA TGT GAT GGT GTC-3', R, 5'-TCT TCC TGG GCT GCT TAT-3'). PCR amplification was performed in $20 \mu \mathrm{l}$ using a thermocycler (Biometra, Germany) with the following PCR program: predenaturation for $3 \mathrm{~min}$ at $94^{\circ} \mathrm{C}$, denaturation for $45 \mathrm{sec}$ at $94^{\circ} \mathrm{C}$, annealing for $45 \mathrm{sec}$ at $55^{\circ} \mathrm{C}$, extension for $45 \mathrm{sec}$ at $72^{\circ} \mathrm{C}$ and a final elongation at $72^{\circ} \mathrm{C}$ for $10 \mathrm{~min}$. $\beta$-actin served as an internal positive control. PCR products were analyzed by $1.5 \%$ agarose gel electrophoresis and band intensity was measured directly on an Alphaimager 2200 analysis system (Alpha Innotech, San Leandro, CA). The amount of each mRNA was expressed as a ratio between S100A14 or S100A4 and B-actin.

Tissue microarray immunohistochemistry. Formalin-fixed and paraffin-embedded tissue array sections were cut into $5-\mu \mathrm{m}$-thick sections (average area $2.0 \mathrm{~cm}^{2}$ ), deparaffinized in xylene and rehydrated. Antigen retrieval was performed in a $650 \mathrm{~W}$ microwave for $10 \mathrm{~min}$. Endogenous peroxidase activity was blocked with $0.3 \%$ hydrogen peroxide. Immuno-
Table I. Distribution of clinicopathological features, S100A14 and S100A4 in patients with colorectal cancer.

Clinicopathological features No. of cases $(\%)$ of patients

All patients

115

Sex

Male

63

54.8

Female

Age at diagnosis

$<60$

55

47.8

$\geq 60$

60

52.2

Tumor site

Proximal colon $\quad 49$

Distal colon 28

42.6

Rectum

Degree of differentiation

Well

17.4

Moderate

20

45.2

Poor

52

37.4

T stage

T1

2.6

T2

16.5

T3

53.9

T4

27.0

$\mathrm{N}$ stage

No

47.8

N1

$\mathrm{N} 2$

33.1

19.1

M stage

M0

M1

84.3

97

15.7

S100A14

Positive

43.5

Negative

50

65

56.5

S100A4

Positive

66

57.4

Negative

49

42.6

histochemistry was performed using Power Vision ${ }^{\mathrm{TM}}$ TwoStep Histostaining (ImmunoVision, USA). A monoclonal antibody specific to human S100A14 (LA-5) was produced in our laboratory. LA-5 (diluted 1:100) or a rabbit antiS100A4 polyclonal antibody (diluted 1:200; NeoMarkers, USA) were incubated on the sections overnight at $4^{\circ} \mathrm{C}$. Antibody binding was visualized using a 3,3-diaminobenzidine (DAB) Kit (Zhongshan Jinqiao, China) according to the manufacturer's instructions. For general negative controls, the primary antibodies were replaced by PBS.

All sections were examined microscopically and scored by two independent pathologists who were blinded to the clinical information pertaining to the subjects. Evaluation of S100A14 and S100A4 immunohistochemical staining was performed according to the percentage of positively 
$\mathbf{A}$
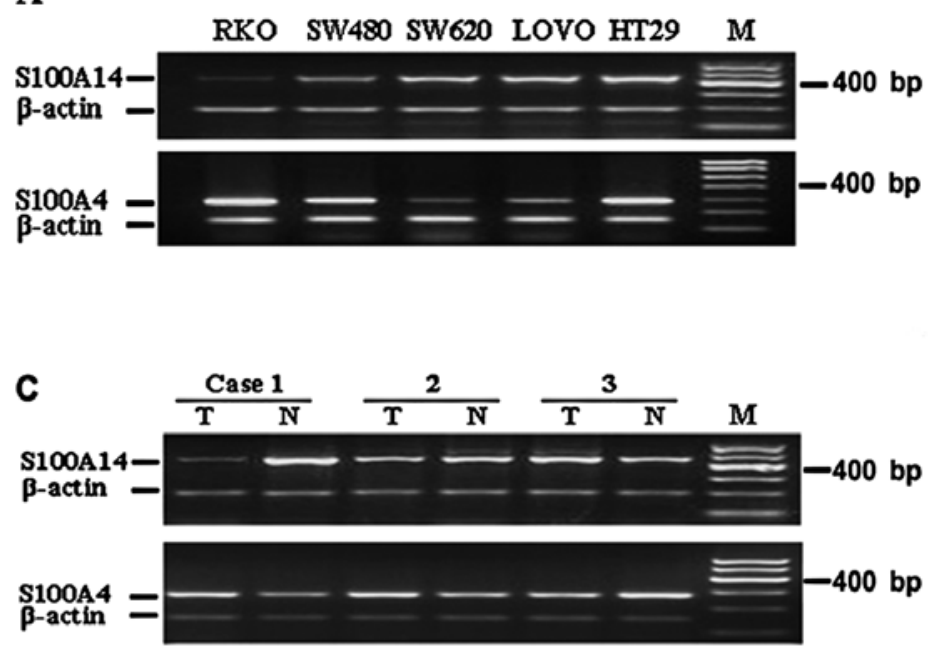

B
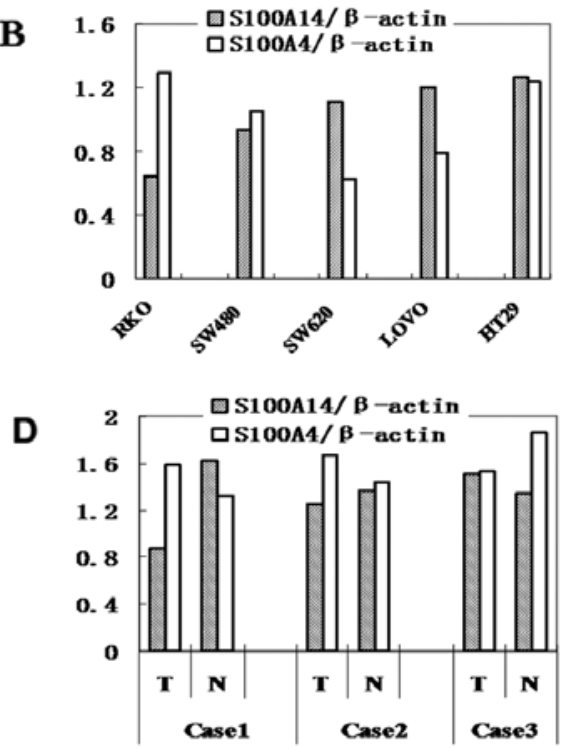

Figure 1. Detection of S100A14/S100A4 mRNA in colorectal cancer cell lines and tissues. (A and B) RT-PCR demonstrated S100A14/S100A4 mRNA expression in five colorectal cancer cell lines: RKO, SW480, SW620, LoVo and HT29. (C and D) Differential expression of S100A14 and S100A4 mRNA was detected in colorectal tumors and matched normal tissues by RT-PCR. B-actin served as an internal control.

stained tumor cells. When $30 \%$ or more of the tumor cells were stained for S100A14 on the cell membrane, the tumors were defined as increased (positive) S100A14 expression. In contrast, the cases were evaluated as decreased (negative) S100A14 expression when S100A14 immunoreactivity was found in $<30 \%$ of the tumor cells. For S100A4, cases in which at least $20 \%$ of the tumor cells were immunoreactive were scored as positive.

Statistical analysis. Statistical analysis was performed using the SPSS software package (version 13.0, SPSS Inc., USA). The $\chi^{2}$ test was used to evaluate relationships between the clinicopathological variables and S100A14 and S100A4 expression. Kaplan-Meier survival analysis with the logrank test was used to evaluate the prognosis of the patients according to their levels of S100A14 and S100A4 expression. Multivariate analysis was performed with the Cox proportional hazards regression model to assess the effects of different variables on patient survival. Differences were considered significant at $\mathrm{P}<0.05$.

\section{Results}

Clinicopathological characteristics at the time of diagnosis in patients with CRC. Sixty-three males and 52 females were included in the study. The mean age of the patients at surgery was 59 years (range, 26-72). There were 49 right-sided tumors, 28 left-sided tumors and 38 rectal tumors (Table I). Clinical follow-up data were available for all patients. The median follow-up was 62 months (range 4-76); 50 of 115 patients $(43.5 \%)$ died of cancer metastasis or local recurrence after surgery.

S100A14 and S100A4 mRNA expression in CRC cell lines. To examine whether S100A14 is expressed in CRC, we firstly examined the expression of S100A14 mRNA in human CRC cell lines (RKO, SW480, SW620, LoVo and HT29). As shown in Fig. 1A, SW480, SW620, LoVo and HT29 cells expressed a substantial amount of S100A14 mRNA, whereas RKO cells only a slight amount. S100A4 mRNA was also detected in these cell lines. RKO, SW480 and HT29 expressed high levels of S100A4 mRNA; lower levels of S100A4 mRNA were found in SW620 and LoVo cells (Fig. 1A). Fig. 1B shows the ratios of S100A14 or S100A4 levels to $ß$-actin in these cell lines.

Among these cell lines, reciprocal expression of S100A14 and S100A4 mRNA was found in four cell lines (RKO, SW480, SW620 and LoVo). Interestingly, our previous study demonstrated that RKO cells had higher hepatic metastasis potential (28).

S100A14 and S100A4 mRNA expression in primary CRC. Next, we examined by RT-PCR the expression levels of S100A14 and S100A4 mRNA in matched samples of primary CRC and adjacent normal mucosa. Of the 40 cases analyzed, we found that S100A14 mRNA was down-regulated in $52.5 \%(21 / 40)$ and up-regulated in $47.5 \%(19 / 40)$ of CRC specimens. In contrast, S100A4 mRNA demonstrated high expression levels in $70.0 \%$ (28/40) and low expression levels in $30.0 \%(12 / 40)$ of samples. S100A14 and S100A4 mRNA expression showed an inverse pattern in primary CRC. Representative examples of the expression level of S100A14 and S100A4 mRNA are shown in Fig. 1C and D.

Association of the immunohistochemical expression status of S100A14 and S100A4 with clinicopathological features. In normal colorectal mucosa, most specimens showed a moderate to strong uniform immunopositivity for S100A14, but the expression of S100A4 was mainly faint or negative. In the present study, negative or absent expression of S100A14 
S100A14
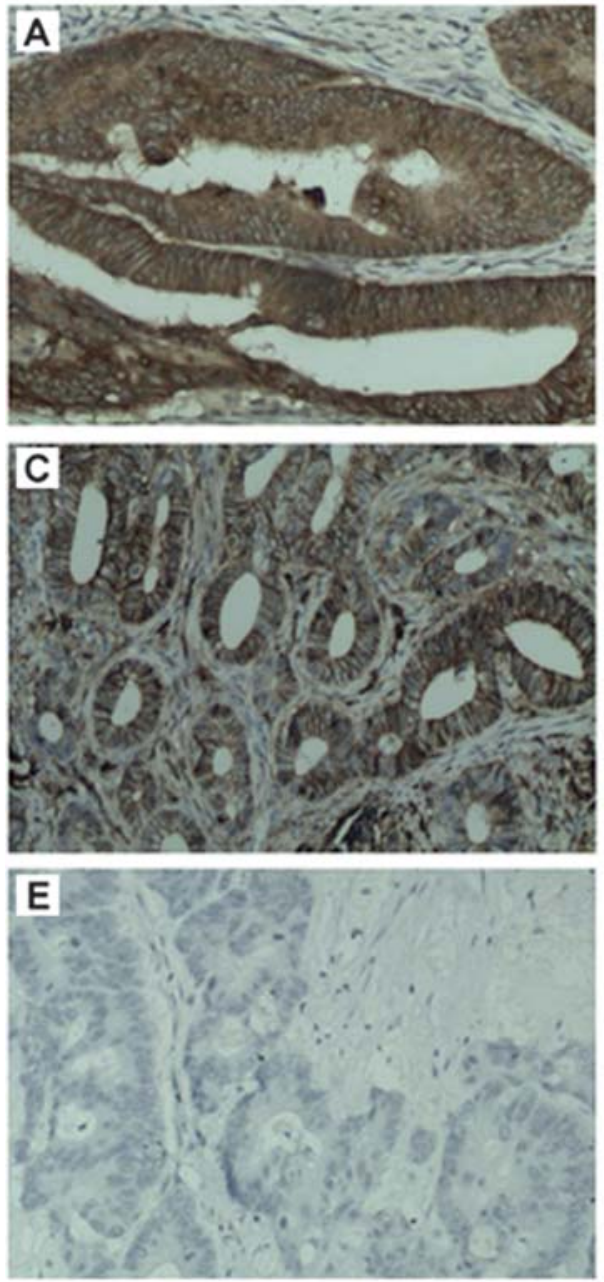

S100A4
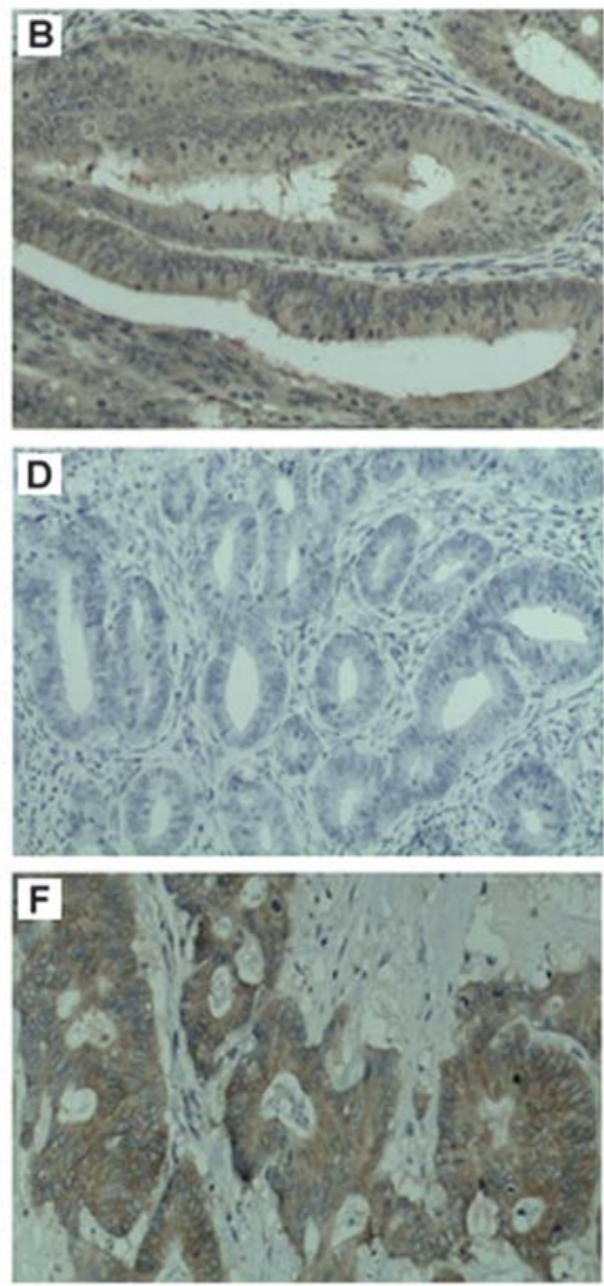

Figure 2. Representative immunohistochemical staining of S100A14 and S100A4 protein in the same tumor. S100A14+/S100A4 ${ }^{+}$tumor $(\mathrm{A}$ and B). S100A14+/S100A4- tumor (C and D). S100A14/S100A4+ tumor (E and F).

was found in $56.5 \%(65 / 115)$ of primary CRC specimens, whereas positive S100A14 expression was detected in $43.5 \%$ (50/115). S100A14 expression was mainly found on the cell membrane of tumor cells, and well-differentiated cancer tended to show uniform S100A14 expression (Fig. 2A and C). Overexpression of S100A4 was observed in $66(57.4 \%)$ cancers. The subcellular location of S100A4 protein was mainly in the cytoplasm (Fig. 2B and F). There was a statistically inverse trend between positive expression of S100A14 and S100A4 ( $\mathrm{P}=0.075)$.

Further analysis of the clinicopathological characteristics of the $115 \mathrm{CRC}$ specimens revealed that there was a significant correlation of S100A14 expression with tumor differentiation and tumor distant metastasis $(\mathrm{P}=0.010$ and $\mathrm{P}=0.048$, respectively). As reported previously, there was also a strong correlation of S100A4-positive expression with lymph node involvement and tumor distant metastasis $(\mathrm{P}=0.001$ and $\mathrm{P}=0.003$, respectively). These results are summarized in Tables II and III.

To our knowledge, this is the first study in which S100A14 and S100A4 expression have been immunohistochemically assessed in CRC and related to clinicopathological findings and prognosis. The CRCs were subdivided into four groups according to the expression status of S100A14 and S100A4 as follows: S100A14/S100A4+, S100A14/S100A4-,

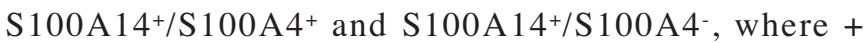
indicates high expression and - indicates low expression. The number of tumors in each group was 42 (36\%), 23 (20\%), 24 (21\%) and 26 (23\%), respectively. Representative immunohistochemical staining of S100A14 and S100A4 protein in the four subgroups is shown in Fig. 2. S100A14\% $\mathrm{S} 100 \mathrm{~A}^{+}{ }^{+}$tumors showed a strong correlation with lymph node involvement and tumor distant metastasis $(\mathrm{P}=0.006$ and $\mathrm{P}<0.001$, respectively) (Table IV). These data suggest that combined analysis of S100A14 and S100A4 expression provides useful information and may enhance accuracy in identifying patients at high risk of regional lymph node or distant metastasis.

Survival analyses of patients according to S100A14 and S100A4 expression status after surgery. Among the 115 CRC patients, the 5-year survival rate was $56.5 \%$. Patients with S100A14- tumors had significantly reduced overall survival compared with those with $\mathrm{S} 100 \mathrm{~A} 14^{+}$tumors $(\mathrm{P}<0.001$, Fig. 3A). In contrast, patients with $\mathrm{S} 100 \mathrm{~A} 4^{+}$tumors had a significantly poorer prognosis than those with S100A4- tumors 
Table II. S100A14 status in relation to clinicopathological features in patients with colorectal cancer [n (\%)].

\begin{tabular}{|c|c|c|c|c|}
\hline \multirow[b]{2}{*}{ Variables } & \multirow[b]{2}{*}{ No. of cases } & \multicolumn{2}{|c|}{ S100A14 } & \multirow[b]{2}{*}{ p-value } \\
\hline & & Positive (\%) & Negative $(\%)$ & \\
\hline \multicolumn{5}{|l|}{ Sex } \\
\hline Male & 63 & $27(42.9)$ & $36(57.1)$ & \\
\hline Female & 52 & $23(44.2)$ & $29(55.8)$ & NS \\
\hline \multicolumn{5}{|l|}{ Age at diagnosis } \\
\hline$<60$ & 55 & $27(49.1)$ & $28(50.9)$ & \\
\hline$\geq 60$ & 60 & $23(38.3)$ & $37(61.7)$ & NS \\
\hline \multicolumn{5}{|l|}{ Tumor site } \\
\hline Proximal colon & 49 & $20(40.8)$ & $29(59.2)$ & \\
\hline Distal colorectum & 66 & $30(45.5)$ & $36(54.5)$ & NS \\
\hline \multicolumn{5}{|c|}{ Degree of differentiation } \\
\hline Well/moderate & 72 & $38(52.8)$ & $34(47.2)$ & \\
\hline Poor & 43 & $12(27.9)$ & $31(72.1)$ & 0.010 \\
\hline \multicolumn{5}{|l|}{ Tumor depth } \\
\hline T1-T2 & 22 & $11(50.0)$ & $11(50.0)$ & \\
\hline T3-T4 & 93 & $39(41.9)$ & $54(58.1)$ & NS \\
\hline \multicolumn{5}{|l|}{ Lymph node status } \\
\hline No & 55 & $28(50.9)$ & $27(49.1)$ & \\
\hline $\mathrm{N} 1-2$ & 60 & $22(36.7)$ & $38(63.3)$ & NS \\
\hline \multicolumn{5}{|l|}{ Distant metastasis } \\
\hline M0 & 97 & $46(47.4)$ & $51(52.6)$ & \\
\hline M1 & 18 & $4(22.2)$ & $14(77.8)$ & 0.048 \\
\hline
\end{tabular}

Table III. S100A4 status in relation to clinicopathological features in patients with colorectal cancer [n (\%)].

\begin{tabular}{|c|c|c|c|c|}
\hline \multirow[b]{2}{*}{ Variables } & \multirow[b]{2}{*}{ No. of cases } & \multicolumn{2}{|c|}{ S100A4 } & \multirow[b]{2}{*}{ p-value } \\
\hline & & Positive (\%) & Negative (\%) & \\
\hline \multicolumn{5}{|l|}{ Sex } \\
\hline Male & 63 & $33(52.4)$ & $30(47.6)$ & \\
\hline Female & 52 & $33(63.5)$ & $19(36.5)$ & NS \\
\hline \multicolumn{5}{|l|}{ Age at diagnosis } \\
\hline$<60$ & 55 & $30(54.5)$ & $25(45.5)$ & \\
\hline$\geq 60$ & 60 & $36(60.0)$ & $24(40.0)$ & NS \\
\hline \multicolumn{5}{|l|}{ Tumor site } \\
\hline Proximal colon & 49 & $25(51.0)$ & $24(49.0)$ & \\
\hline Distal colorectum & 66 & $41(62.1)$ & $25(37.9)$ & NS \\
\hline \multicolumn{5}{|c|}{ Degree of differentiation } \\
\hline Well/moderate & 72 & $39(54.2)$ & $33(45.8)$ & \\
\hline Poor & 43 & $27(62.8)$ & $16(37.2)$ & NS \\
\hline \multicolumn{5}{|l|}{ Tumor depth } \\
\hline T1-T2 & 22 & $12(54.6)$ & $10(45.4)$ & \\
\hline T3-T4 & 93 & $54(58.1)$ & $39(41.9)$ & NS \\
\hline \multicolumn{5}{|l|}{ Lymph node status } \\
\hline No & 55 & $23(41.8)$ & $32(58.2)$ & \\
\hline $\mathrm{N} 1-2$ & 60 & $43(71.7)$ & $17(28.3)$ & 0.001 \\
\hline \multicolumn{5}{|l|}{ Distant metastasis } \\
\hline M0 & 97 & $50(51.5)$ & $47(48.5)$ & \\
\hline M1 & 18 & $16(88.9)$ & $2(11.1)$ & 0.003 \\
\hline
\end{tabular}

NS, not significant. 
Table IV. S100A14 and S100A4 status in relation to clinicopathological features in patients with colorectal cancer [n (\%)].

\begin{tabular}{|c|c|c|c|c|c|}
\hline \multirow[b]{2}{*}{ Variables } & \multirow[b]{2}{*}{ No. of cases } & \multicolumn{3}{|c|}{ S100A14 and S100A4 expression } & \multirow[b]{2}{*}{ p-value } \\
\hline & & $\mathrm{A} 14^{-} / \mathrm{A} 4^{+}$ & $\mathrm{A} 14^{-} / \mathrm{A} 4^{-}$or $\mathrm{A} 14^{+} / \mathrm{A} 4^{+}$ & $\mathrm{A} 14^{+} / \mathrm{A} 4^{-}$ & \\
\hline \multicolumn{6}{|l|}{$\overline{S e x}$} \\
\hline Male & 63 & $20(31.7)$ & $29(46.0)$ & $14(22.2)$ & \\
\hline Female & 52 & $22(42.3)$ & $18(34.6)$ & $12(23.1)$ & NS \\
\hline \multicolumn{6}{|l|}{ Age at diagnosis } \\
\hline$<60$ & 55 & $16(29.1)$ & $23(41.8)$ & $16(29.1)$ & \\
\hline$\geq 60$ & 60 & $26(43.3)$ & $24(40.0)$ & $10(16.7)$ & NS \\
\hline \multicolumn{6}{|l|}{ Tumor site } \\
\hline Proximal colon & 49 & $26(53.1)$ & $8(16.3)$ & $15(30.6)$ & \\
\hline Distal colorectum & 66 & $16(24.2)$ & $39(59.1)$ & $11(16.7)$ & NS \\
\hline \multicolumn{6}{|c|}{ Degree of differentiation } \\
\hline Well/moderate & 72 & $19(26.4)$ & $30(41.7)$ & $23(31.9)$ & \\
\hline Poor & 43 & $23(53.5)$ & $17(39.5)$ & $3(7.0)$ & NS \\
\hline \multicolumn{6}{|l|}{ Tumor depth } \\
\hline $\mathrm{T} 1-\mathrm{T} 2$ & 22 & $7(31.8)$ & $9(40.9)$ & $6(27.3)$ & \\
\hline $\mathrm{T} 3-\mathrm{T} 4$ & 93 & $35(37.6)$ & $38(40.9)$ & $20(21.5)$ & NS \\
\hline \multicolumn{6}{|l|}{ Lymph node status } \\
\hline No & 55 & $12(21.8)$ & $26(47.3)$ & $17(30.9)$ & \\
\hline $\mathrm{N} 1-2$ & 60 & $30(50.0)$ & $21(35.0)$ & $9(15.0)$ & 0.006 \\
\hline \multicolumn{6}{|l|}{ Distant metastasis } \\
\hline M0 & 97 & $29(29.9)$ & $43(44.3)$ & $25(25.8)$ & \\
\hline M1 & 18 & $13(72.2)$ & $4(22.2)$ & $1(5.6)$ & $<0.001$ \\
\hline
\end{tabular}

NS, not significant.

Table V. Multivariate analysis of prognostic factors in patients with colorectal cancer.

\begin{tabular}{|c|c|c|c|c|}
\hline Variables & Indicator of poor prognosis & $\mathrm{RR}$ & $95 \% \mathrm{CI}$ & p-value \\
\hline Distant metastasis & M1 & 5.25 & $2.94-9.38$ & $<0.001$ \\
\hline S100A14/S100A4 status & S100A14-/S100A4+ & 3.11 & $1.46-6.61$ & 0.006 \\
\hline S100A14 expression & Negative & 2.54 & $1.27-5.12$ & 0.030 \\
\hline
\end{tabular}

$\mathrm{RR}$, relative risk; CI, confidence interval.

( $\mathrm{P}=0.009$, Fig. 3B). Subsequently, we analyzed the survival curves of the four groups according to the expression status of S100A14 and S100A4. Patients with S100A14+/S100A4tumors had the longest survival among these groups. The S100A14-/S100A4 group and the $\mathrm{S} 100 \mathrm{~A} 14^{+} / \mathrm{S} 100 \mathrm{~A} 4^{+}$group showed similar survival curves. The S100A14/S100A4+ group had the poorest survival $(\mathrm{P}<0.001$, Fig. 3C).

Furthermore, we analyzed our data with a Cox proportional hazards model using tumor differentiation, lymph node involvement, tumor distant metastasis and S100A14/ S100A4 expression status as covariates. Tumor distant metastasis was the strongest prognostic factor, S100A14 expression and S100A14-/S100A4+ expression status were independent prognosis factors (Table V).

\section{Discussion}

To our knowledge, this is the first study showing the status of S100A14 expression in a large series of CRC patients. S100A14 was identified as being a useful marker, adding prognostic information to the clinical course of patients with CRC. Interestingly, our results revealed that reduced expression of S100A14 tended to co-occur with increased expression of S100A4 in CRC cell lines and tissue specimens, as demonstrated by RT-PCR analysis and immunohistochemistry.

In the present study, we evaluated the expression of S100A14, and correlated this with the clinical features of patients with CRC. The expression and subcellular location 


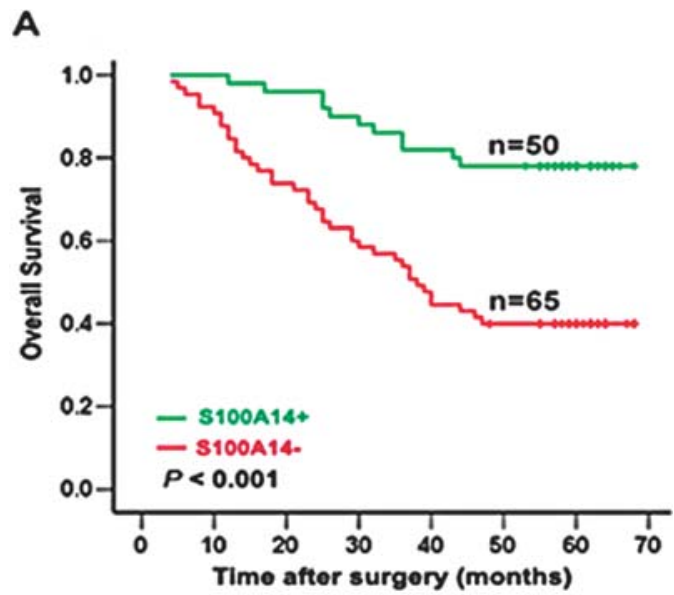

B

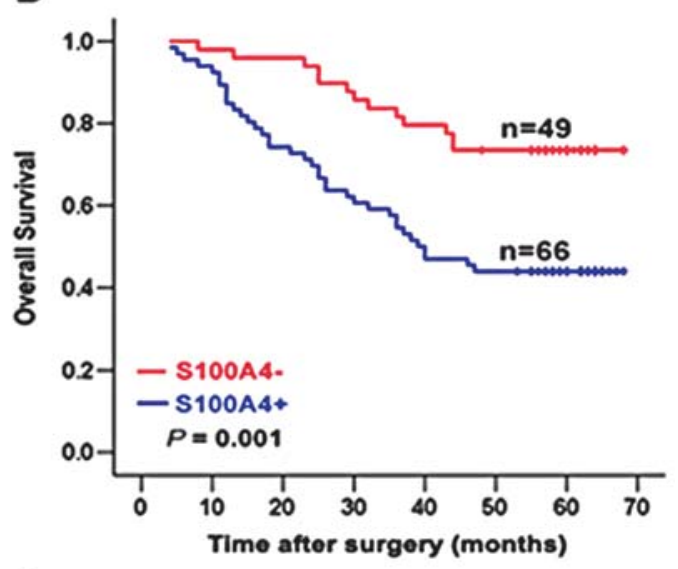

C

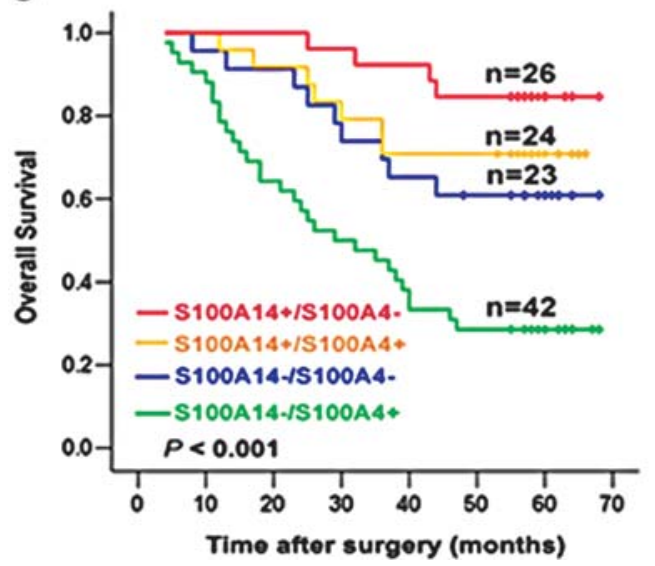

Figure 3. Kaplan-Meier overall survival analysis of colorectal cancer patients according to the expression status of S100A14 (A), S100A4 (B) and the combined expression of S100A14 and S100A4 (C).

of S100A14 protein was studied by immunohistochemistry in 115 CRCs and matched normal colorectal mucosal specimens. These results revealed that S100A14 was mainly expressed in the cell membrane of the epithelial cells; most of the normal colorectal mucosal specimens showed homogeneous immunopositivity. In CRC, positive S100A14 expression was detected in $43.5 \%$ of cancers, whereas negative or absent S100A14 expression was found in $56.5 \%$. Consistent with these results, S100A14 mRNA was differentially expressed in CRC cell lines and matched samples of primary CRC and adjacent normal mucosa. Among 40 cases analyzed, we found that $5100 A 14$ mRNA was up-regulated in $47.5 \%$ and down-regulated in $52.5 \%$. Previous studies have provided evidence for differential expression of S100A14 in ovarian, breast, kidney and uterine tumors, suggesting a potentially important function for this gene in malignant transformation (20).

Based on our immunohistochemical assessment, we further analyzed the association between S100A14 expression and clinicopathologic variables. Strong correlations were found between S100A14 expression and the degree of tumor differentiation. A higher incidence of S100A14 expression was observed in well- and moderately-differentiated tumors, which indicated that this protein might function in cell differentiation. Our results agree with a previous report that some members of the $\mathrm{S} 100$ protein family are involved in cell differentiation (29).

S100A4 was believed to be a metastasis-inducing protein and associated with cancer invasion and metastasis because S100A4 protein secreted from tumor cells can increase endothelial cell motility and induce angiogenesis (30). Immunohistochemical expression of S100A4 has been proven to be a highly significant, independent prognostic marker in a large series of CRC patients (18). In the present study, overexpression of S100A4 was found in $66(57.4 \%)$ of 115 CRC specimens and was closely associated with metastatic potential and poor prognosis of CRC. Flatmark et al (13) reported that overexpression of S100A4 was more frequently found in liver metastases than in primary tumors. These data further support the significant correlation between over-expression of S100A4 and progression of CRC.

Currently, other than the stage of the tumor at the time of the resection, few molecular markers are accepted as indicators of prognosis in CRC. This is mainly due to the conflicting results reported in the literature. Several studies have indicated that altered expression of S100 members such as S100A2, S100A4, S100A6, S100A11, S100C and S100P might be informative markers for genesis, progression and prognosis in some human tumors including gastric cancer, CRC, esophageal cancer and gall bladder cancer (31-35). A recent study proposed that stratification of patients into groups according to the expression of S100A4 and S100P might facilitate more accurate prediction of survival in breast cancer patients (36). Our studies showed that S100A14 $/$ S100A4+ CRC had a highly invasive and metastatic potential, compared with S100A14+/S100A4- tumors. Furthermore, S100A14/S100A4+ status was specifically correlated with lymph node and distant metastasis. The Cox proportional hazard model demonstrated that S100A14/S100A4+ CRC had a 3-fold higher relative risk of death than S100A14+/ S100A4- CRC. These results suggest that a combined analysis of S100A14 and S100A4 expression status may enhance our accuracy in identifying patients at high risk of regional lymph node or distant metastasis, and hence provide useful information for clinical management.

In conclusion, our study demonstrated that S100A14 and S100A4 expression plays a role in the progression and metastasis of CRC. The simultaneous immunohistochemical detection of S100A14 and S100A4 expression may be useful to evaluate the prognosis of patients with CRC. 


\section{Acknowledgements}

This study was supported by grants from the State Key Basic Research Program, No. 2004 CB518708, National Bio-Tech 86-3, No. 2006AA02A402 and Key Projects in the National Science \& Technology Pillar Program in the Eleventh Fiveyear Plan Period (2006BAI02A14).

\section{References}

1. Santamaria-Kisiel L, Rintala-Dempsey AC and Shaw GS Calcium-dependent and -independent interactions of the S100 protein family. Biochem J 396: 201-214, 2006.

2. Donato R: S100: a multigenic family of calcium-modulated proteins of EF-hand type with intracellular and extracellular functional roles. Int J Biochem Cell Biol 33: 637-668, 2001.

3. Kriajevska M, Tarabykina S, Bronstein I, Maitland N, Lomonosov M, Hansen K, Georgiev G and Lukanidin E: Metastasis-associated 1 (S100A4) protein modulates protein kinase $\mathrm{C}$ phosphorylation of the heavy chain of non-muscle myosin. J Biol Chem 273: 9852-9856, 1998.

4. Gimona M, Lando Z, Dolginov Y, Vandekerckhove J, Kobayashi R, Sobieszek A and Helfman DM: $\mathrm{Ca}^{2+}$-dependent interaction of S100A2 with muscle and non-muscle tropomyosins. J Cell Sci 110: 611-621, 1997.

5. Zimmer DB, Cornwall EH, Landar A and Song W: The S100 protein family: history, function, and expression. Brain Res Bull 37: 417-429, 1995

6. Sherbet GV and Lakshmi MS: S100A4 (MTS1) calcium binding protein in cancer growth, invasion and metastasis. Anticancer Res 18: 2415-2421, 1998.

7. Davies BR, Davies MP, Gibbs FE, Barraclough R and Rudland PS Induction of the metastatic phenotype by transfection of a benign rat mammary epithelial cell line with the gene for p9Ka, a rat calcium-binding protein, but not with the oncogene EJ-ras-1. Oncogene 8: 999-1008, 1993

8. Ebralidze A, Tulchinsky E, Grigorian M, Afanasyeva A, Senin V, Revazova $\mathrm{E}$ and Lukanidin E: Isolation and characterization of a gene specifically expressed in different metastatic cells and whose deduced gene product has a high degree of homology to a $\mathrm{Ca}^{2+}$-binding protein family. Genes Dev 3: 1086-1093, 1989.

9. Yonemura Y, Endou Y, Kimura K, Fushida S, Bandou E, Taniguchi K, Kinoshita K, Ninomiya I, Sugiyama K, Heizmann CW, Schafer BW and Sasaki T: Inverse expression of S100A4 and E-cadherin is associated with metastatic potential in gastric cancer. Clin Cancer Res 6: 4234-4242, 2000.

10. Cho YG, Nam SW, Kim TY, Kim YS, Kim CJ, Park JY, Lee JH, Kim HS, Lee JW, Park CH, Song YH and Lee SH: Overexpression of S100A4 is closely related to the aggressiveness of gastric cancer. APMIS 111: 539-545, 2003.

11. Takenaga K, Nakanishi H, Wada K, Suzuki M, Matsuzaki O, Matsuura A and Endo H: Increased expression of S100A4, a metastasis-associated gene, in human colorectal adenocarcinomas. Clin Cancer Res 3: 2309-2316, 1997.

12. Taylor S, Herrington S, Prime W, Rudland PS and Barraclough R: S100A4 (p9Ka) protein in colon carcinoma and liver metastases: association with carcinoma cells and T-lymphocytes. Br J Cancer 86: 409-416, 2002.

13. Flatmark K, Pedersen KB, Nesland JM, Rasmussen H, Aamodt G, Mikalsen SO, Bjornland K, Fodstad O and Maelandsmo GM: Nuclear localization of the metastasis-related protein S100A4 correlates with tumour stage in colorectal cancer. J Pathol 200: 589-595, 2003

14. Rudland PS, Platt-Higgins A, Renshaw C, West CR, Winstanley JH, Robertson L and Barraclough R: Prognostic significance of the metastasis-inducing protein $\mathrm{S} 100 \mathrm{~A} 4(\mathrm{p} 9 \mathrm{Ka})$ in human breast cancer. Cancer Res 60: 1595-1603, 2000.

15. Ninomiya I, Ohta T, Fushida S, Endo Y, Hashimoto T, Yagi M, Fujimura T, Nishimura G, Tani T, Shimizu K, Yonemura Y, Heizmann CW, Schafer BW, Sasaki T and Miwa K: Increased expression of S100A4 and its prognostic significance in esophageal squamous cell carcinoma. Int J Oncol 18: 715-720, 2001

16. Nakamura T, Ajiki T, Murao S, Kamigaki T, Maeda S, Ku Y and Kuroda Y: Prognostic significance of S100A4 expression in gallbladder cancer. Int J Oncol 20: 937-941, 2002.
17. Kimura K, Endo Y, Yonemura Y, Heizmann CW, Schafer BW, Watanabe Y and Sasaki T: Clinical significance of S100A4 and E-cadherin-related adhesion molecules in non-small cell lung cancer. Int J Oncol 16: 1125-1131, 2000.

18. Gongoll S, Peters G, Mengel M, Piso P, Klempnauer J, Kreipe H and von Wasielewski R: Prognostic significance of calciumbinding protein S100A4 in colorectal cancer. Gastroenterology 123: 1478-1484, 2002

19. Hemandas AK, Salto-Tellez M, Maricar SH, Leong AF and Leow CK: Metastasis-associated protein S100A4 - a potential prognostic marker for colorectal cancer. J Surg Oncol 93: 498-503, 2006.

20. Pietas A, Schluns K, Marenholz I, Schafer BW, Heizmann CW and Petersen I: Molecular cloning and characterization of the human S100A14 gene encoding a novel member of the S100 family. Genomics 79: 513-522, 2002.

21. Ilg EC, Schafer BW and Heizmann CW: Expression pattern of S100 calcium-binding proteins in human tumors. Int J Cancer 68: 325-332, 1996.

22. Wicki R, Franz C, Scholl FA, Heizmann CW and Schafer BW: Repression of the candidate tumor suppressor gene S100A2 in breast cancer is mediated by site-specific hypermethylation. Cell Calcium 22: 243-254, 1997.

23. Sakaguchi M, Miyazaki M, Inoue Y, Tsuji T, Kouchi H, Tanaka T, Yamada $\mathrm{H}$ and Namba M: Relationship between contact inhibition and intranuclear S100C of normal human fibroblasts. J Cell Biol 149: 1193-1206, 2000.

24. Gribenko AV, Hopper JE and Makhatadze GI: Molecular characterization and tissue distribution of a novel member of the S100 family of EF-hand proteins. Biochemistry 40: 15538-15548, 2001

25. Tang Z, Zhao M, Ji J, Yang G, Hu F, He J, Shen H, Gao Z, Zhao A, Li J and Lu Y: Overexpression of gastrin and c-met protein involved in human gastric carcinomas and intestinal metaplasia. Oncol Rep 11: 333-339, 2004

26. American Joint Committee on Cancer: Cancer Staging Manual. 5th edition. Lippincott-Raven, Philadelphia, pp83-88, 1997.

27. Lanza G, Gafa R, Santini A, Maestri I, Dubini A, Gilli G and Cavazzini L: Prognostic significance of DNA ploidy in patients with stage II and stage III colon carcinoma: a prospective flow cytometric study. Cancer 82: 49-59, 1998.

28. Kang B, Hao C, Wang H, Zhang J, Xing R, Shao J, Li W, Xu N, $\mathrm{Lu} \mathrm{Y}$ and Liu S: Evaluation of hepatic-metastasis risk of colorectal cancer upon the protein signature of PI3K/AKT pathway. J Proteome Res 7: 3507-3515, 2008.

29. Robinson NA, Lapic S, Welter JF and Eckert RL: S100A11, S100A10, annexin I, desmosomal proteins, small proline-rich proteins, plasminogen activator inhibitor-2, and involucrin are components of the cornified envelope of cultured human epidermal keratinocytes. J Biol Chem 272: 12035-12046, 1997.

30. Ambartsumian N, Klingelhofer J, Grigorian M, Christensen C, Kriajevska M, Tulchinsky E, Georgiev G, Berezin V, Bock E, Rygaard J, Cao R, Cao Y and Lukanidin E: The metastasisassociated Mts1(S100A4) protein could act as an angiogenic factor. Oncogene 20: 4685-4695, 2001.

31. El-Rifai W, Moskaluk CA, Abdrabbo MK, Harper J, Yoshida C, Riggins GJ, Frierson HF Jr and Powell SM: Gastric cancers overexpress S100A calcium-binding proteins. Cancer Res 62: 6823-6826, 2002

32. Oue N, Hamai Y, Mitani Y, Matsumura S, Oshimo Y, Aung PP, Kuraoka K, Nakayama H and Yasui W: Gene expression profile of gastric carcinoma: identification of genes and tags potentially involved in invasion, metastasis, and carcinogenesis by serial analysis of gene expression. Cancer Res 64: 2397-2405, 2004.

33. Shyu RY, Huang SL and Jiang SY: Retinoic acid increases expression of the calcium-binding protein $\mathrm{S} 100 \mathrm{P}$ in human gastric cancer cells. J Biomed Sci 10: 313-319, 2003.

34. Kyriazanos ID, Tachibana M, Dhar DK, Shibakita M, Ono T, Kohno $\mathrm{H}$ and Nagasue N: Expression and prognostic significance of S100A2 protein in squamous cell carcinoma of the esophagus. Oncol Rep 9: 503-510, 2002.

35. Memon AA, Sorensen BS, Meldgaard P, Fokdal L, Thykjaer T and Nexo E: Down-regulation of S100C is associated with bladder cancer progression and poor survival. Clin Cancer Res 11: 606-611, 2005.

36. Wang G, Platt-Higgins A, Carroll J, De Silva Rudland S, Winstanley J, Barraclough R and Rudland PS: Induction of metastasis by $\mathrm{S} 100 \mathrm{P}$ in a rat mammary model and its association with poor survival of breast cancer patients. Cancer Res 66: 1199-1207, 2006. 